\title{
NOTES
}

\section{IMPROVING THE ADOPTION PROCESS: THE PENNSYLVANIA ADOPTION ACT}

The practice of adoption is of ancient origin, ${ }^{1}$ and the history of its growth and development is an interesting story of changing social and legal concepts. ${ }^{2}$ In virtually every country in the world, adoption has existed as a social institution in order to provide care for parentless and neglected children and to perpetuate family titles and estates. ${ }^{3}$ The practice of adoption gradually achieved legal recognition and became the subject of legislation in several ancient nations; ${ }^{4}$ later the nations of continental Europe inherited a system of adoption from the Roman civil law. 5 However, legal adoption, i.e., the transfer by law of parental rights and duties to someone other than the natural parents, was unknown at English common law, and the rights, liabilities and duties of parents were inalienable. ${ }^{6}$ In fact, it was

1. The earliest record mentioning adoption is Art. 185 of the Code of Hammurabi, dating back beyond 2000 B.C. "If a man take in his name a young child as a son, and rear him, one may not bring claim for that adopted son." THE CODE OF HaMMURABI 69 (Harper ed. 1904).

2. See Reighard, A Comparative Study of Adoption Law in Four States (1950) (Treatise on file in the research library of the Health and Welfare Council of Philadelphia); Quarles, The Laze of Adoption- A Legal Anomaly, 32 Marq. L. Rev. 237 (1949); MaIne, Ancient Law (10th ed. 1906).

3. See note 2 supra. See also, Bishop, Adoption in Soctar Work Year Book 25 (11th ed. 1951). The Hindu culture presents an example of a situation in which there may arise the need for adoption in order to pass estates. "Among the Hindoos, the right to inherit a dead man's property is exactly co-extensive with the duty of performing his obsequies. If the rites are not properly performed or not performed by the proper person, no relation is considered as established between the deceased and anybody surviving him; the Law of Succession does not apply, and nobody can inherit the property. Every great event in the life of a Hindoo seems to be regarded as leading up to and bearing upon these solemnities. If he marries, it is to have children who may celebrate them after his death; if he has no children, he lives under the strongst obligation to adopt them from another family, 'with a view,' writes the Hindoo doctor, 'to the funeral cake, the water and the solemn sacrifice." MAINE, ANCIENT LaW 204 (10th ed. 1906). Evidences of adoption practice are found in the Bible: Moses was adopted by Pharaoh's daughter, Exodus 2:5-10; and Esther by Mordecai, Esther 2:5-7. Adoption was well practiced by the Greeks, Egyptians and Babylonians, Lamb v. Feehan, 276 S.W. 71, 78 (Mo. Supp. 1925) ; In re Kirby's Estate, 145 Misc. 756, 758, 261 N.Y.S. 71, 72 (1932), and by the ancient Germans, Matter of Thorne, 155 N.Y. 140, 143, 49 N.E. 661,662 (1898).

4. "In Greece, in the interests of next of kin whose rights were affected by the case of adoption, it was provided that the registration should be attended with certain formalities, and that it should take place at a fixed time, the festival of Thargelia.

"In Rome the system was in vogue long before the time of Justinian . . . but he reduced the system to a code. - ." Morrison v. Sessions Estate, 70 Mich. $297,306,38$ N.W. 249, 253 (1888). For a complete analysis of the Roman law of adoption before and after Justinian's codification, see SANDARS, ThE INSTITUTES OF JUSTINLAN 40-47 (1905). See also note 1 supra.

5. See 1 Encyc. Soc. ScI. 461 (1937); Retgeard, op. cit. supra note 2, at 2.

6. See Humphrys v. Polak, [1901] 2 K.B. 385, 390 (C.A.) ; Poole v. Stokes, 110 I.T. 1020 (1914); Fleming v. Roburite Co., 10 B.W.C.C. 176 (C.A. 1917); Brooks v. Blount, [1923] 1 K.B. 257. "In English law the child had no absolute right to succeed to any part of the parent's property, but could be disinherited by 
not until the passage of the Adoption of Children Act in 1926 that a system of legal adoption was introduced into Great Britain. ${ }^{7}$

In the United States, Texas and Louisiana inherited much of the Spanish and French civil law and with it a system of legal adoption. ${ }^{8}$ The vast majority of jurisdictions, however, inherited no system of legal adoption since they followed the English common law. Initially, legal adoption was sometimes accomplished by a special statute validating the particular adoption. ${ }^{9}$ Beginning with Massachusetts in $1851,{ }^{10}$ the states gradually passed general adoption legislation. ${ }^{11}$ Although the motivation for these statutes is not clear, it has been suggested that the civil law as reflected in Texas and Louisiana influenced their development. ${ }^{12}$ A number of these early statutes provided merely for evidence of the child's transfer by requiring a deed which was to be recorded in the same manner as a property deed. ${ }^{13}$

will in favor of either relatives or strangers. It was possible, therefore, without resort to adoption, for family titles to be continued and family estates kept together when there was no direct male descendant. Provision for care of dependent children by means of adoption was probably delayed by the development of the relation of master and apprentice. By means of this arrangement orphans and children of indigent parents could be bound out, while the rights of the master and of the parent under this relationship were defined by law." 1 ENCYc. Soc. SCI. 461 (1937). At common law, however, it was possible for a relative or a stranger to put himself in loco parentis towards a child, so as to place himself in a fiduciary position in his relations with that child. Powys v. Mansfield, 3 My. \& Cr. 359, 366 (1837).

7. 16 \& 17 GEo. 5, c. 29 (1926). Cf. Ward v. Dorman Long \& Co., [1933] 2 K.B. 658 (C.A.).

8. See State ex rel. Walton v. Yturria, 109 Tex. 220, 204 S.W. 315 (1918); Vidal v. Commagére, 13 La. Ann. 516 (1858). See also ReIGHARD, op. cit. supra note 2; 1 ENCY. BRrT. 178 (1953); 3 LA. LEGAL ARCHIVEs, 124, 125 (1940) (CODE of NAPOLEON, art. 343 (1804)).

9. See Sayles v. Christie, 187 IIl. 420, 58 N.E. 480 (1900); Bedal v. Johnson, 37 Idaho 359, 218 Pac. 641 (1923); Vidal v. Commagére, 13 La. Ann. 516 (1858) (Louisiana used private statutes after the repeal of the adoption law in 1808. A new general statute was enacted in 1870). This last case grows out of the second section of the Act of March 15, 1837, which is as follows:

"Be it enacted, Ec.; 'That Pierre Jean Baptiste Vidal and Félicité Blanche Power, of the parish of Orleans, be authorized to adopt a young orphan child named Adele, aged about seven years, who has been brought up by them; provided the adoption be executed by act signed before a Notary Public in said parish of Orleans, within six months after the passage of this law."

Id. at 517. Private laws were also passed in Wisconsin. See Quarles, The Law of Adoption-A Legal Anomaly, 32 Marg. L. Rev. 237, 241 (1949).

10. Mass. Laws 1851, p. 324.

11. See White v. Kwock Sue Lum, 291 Fed. 732 (9th Cir. 1923) ; Weinbach's Appeal, 316 Pa. 333, 175 Atl. 500 (1934); Schwab Adoption Cases, 355 Pa. 534, 50 A.2d 504 (1947). See also 4 Vernier, Amerrcan Family Laws $\$ 254$ (1936). Compare 1 ENCYC. Soc. ScI. 461 et seq. (1937).

12. See Morrison v. Sessions Estate, 70 Mich. 297, 306, 38 N.W. 249, 253 (1888); Hochaday v. Lynn, 200 Mo. 456, 98 S.W. 585 (1906); Woodward's Appeal, 81 Conn. 152, 70 At1. 453 (1908); In re Petition of Ritchie, 155 Neb. 824, 53 N.W.2d 753 (1952). See also ReIghard, op. cit. supra note 2, at 2.

13. This type of provision existed in Pennsylvania before 1925 under $\mathrm{Pa}$. Laws 1872, No. 20, p. 31. See also Ala. CoDe 1886, \$2367; Vt. Acts 1880, No. 137, §5; Iowa Laws 1858 , c. $67, \S \S 2-4$; Tex. Gen. Laws $1849-50$, c. 39 , p. 36. 
The philosophy manifested by some of the early statutes, that adoption merely involves the transfer of a particular species of chattel, has been slow to disappear from the legal scene. ${ }^{14}$ Nevertheless, in recent years adoption has come to be recognized as involving factors of vital importance to the community. More than establishing a new legal relationship, adoption initiates an emotional and psychological relationship which, if unsuccessful or unwarranted, could cause serious injury, both personal and social.15 Because of this expanding concept of adoption, the objectives of adoption statutes have been generally enlarged to include: protection of the child against unnecessary separation from natural parents and adoption by persons unfit to have the responsibility of rearing a child; protection of the natural parents against their own hasty decisions to give up the child; and protection of adopting parents against such risks as taking the responsibility for children whose mental and physical capacities or heredity are unknown. ${ }^{16}$

However, the statutory provisions enacted initially to effectuate these objectives were far from adequate. In many jurisdictions adoption placement could be made by anyone. ${ }^{17}$ The child could be placed in an adoptive home before the consent of the natural parent to the proposed adoption was legally ascertained, ${ }^{18}$ and suitability of the adoptive home was seldom established. ${ }^{10}$ The need for further amendment was patent, particularly during the last decade. Between 1944 and 1951 it is estimated that adoption petitions throughout the country increased by $60 \% .{ }^{20}$ As a result of the

14. In Pennsylvania it was not until the Act of April 4, 1925, Pa. Laws 1925, No. 93 , p. 127, that the transfer by deed statute of 1872 was repealed. Texas and Iowa have repealed their statutes within the last thirty years. See ReIGHARD, op. cit. supra note 2 , at 3 .

15. Bishop, Adoption in Socras. Work Yearboor 25 (11th ed. 1951).

16. See statutes cited in notes 18,19 infra. These three objectives are specifically set forth in ChIldren's Bureau PuB., No. 331 (Fed. Security Agency 1949). This pamphlet also presents a comprehensive examination of desirable provisions to be incorporated in an ideal adoption statute.

17. See, e.g., Lee v. Thomas, $297 \mathrm{Ky} .858,181$ S.W.2d 457 (1944) (child placed by a doctor); Wyness v. Crowley, 292 Mass. 459, 198 N.E. 758 (1935) (by a doctor) ; In re Estate of De Sot. 134 Neb. 371, 278 N.W. 852 (1938) (by hospital superintendent); In re Candalaria's Estate, 41 N.M. 211, 67 P.2d 235 (1937) (by natural parents themselves); Diana Adoption Case, $165 \mathrm{~Pa}$. Super. 12, $67 \mathrm{~A} .2 \mathrm{~d} 751$ (1949) (by a doctor). See also Note, 59 YALE L.J. 715 n.2 (1950).

18. Under the prior Pennsylvania provision consent was not legally determined until the time of the adoption hearing although some acquiesence must have been given by natural parents previously. See PA. STAT. Ans. tit. 1, §3 (Purdon 1952). See also, e.g., IDAHo Code ANN. tit. 3, c. 16, \$1506 (1948); N.M. LAws 1893, c. 32, $\$ 7$, repealed by N.M. Laws 1925 , c. $5, \$ \S 1,4$; NEW YoRK Domestic ReLATIons LAW $\$ 112(1,5) ;$ S.D. CODE $\$ 14.0406$ (Supp. 1952).

19. As of 1936 there was no provision for investigation of the adoptive home in 24 states. See 4 Vernier, American Fammly Laws 294 (1936). In the states in which an investigatory provision did exist, frequently the investigation was discretionary with the court and sketchy in nature, and in almost every instance investigation was not made until the time of the adoption hearing. See, e.g., id. at 298 (Ala. statute), 312 (Mass.), 312 (Md.), 336 (Wyo.), 326 (Pa.), 326 (Ore.).

20. In 1951 the number of adoption petitions filed in the United States probably reached 80,000. Among the factors accounting for the increase were the large number of homes broken by death, divorce, and desertion during and following World War II; the increase in the number of illegitimate children born since 1944; and the growing antipathy toward long periods of institutionalization. CEILDREN's 
magnitude of the problem, since 1948 more than half of the states have passed new adoption acts or amended existing ones. ${ }^{21}$

The growth of legal adoption in Pennsylvania has been consistent with the general development in the United States. Prior to 1855, the adoption status could be created only by a special act of the legislature.22 In 1855 a statute was enacted enabling a person to petition the court for a decree of adoption. ${ }^{23}$ Subsequently, adoption by deed was authorized, ${ }^{24}$ and some persons whose petitions had been denied utilized this method of securing an adoption. ${ }^{25}$ In 1925 the legislature repealed all acts relating to adoption and passed a new statute. ${ }^{26}$ This statute, however, was subject to the same general deficiencies outlined above. ${ }^{27}$ In keeping with the national trend, and spurred by the considerable increase in adoptions in this state between 1944 and 1951,28 the legislature amended the adoption law extensively by an act which became effective on January 1, 1954.29 The purpose of this act is to protect the rights of the chiid, the natural parent, and the adoptive parents. ${ }^{30}$ The act requires that under certain conditions persons receiving children for adoption must file a report and submit to an investigation of the suitability of their home. Under this provision the child's background is also investigated. ${ }^{31}$ It is provided that the issues of consent and abandonment may be determined prior to the time of the hearing on

Bureau Statisticai Ser., No. 14 (Dep't Health, Educ. and Welfare 1951). This pamphlet represents the latest statistical compilation regarding the adoption of children. See communication from Edward E. Schwartz, Chief, Program Analysis Branch, Department of Health, Education and Welfare, Washington, D. C., February 26, 1954, on file, Biddle Law Library, University of Pennsylvania Law School.

21. See, e.g., Del. Laws 1933, c. 162, 163, Del. Laws 1935, c. 212-16, as amended, DEL REv. CODE c. $13 \$ \$ 901-28$ (1953) ; Iowa Acts 1927, c. 218, \$\$1-8, as amended, Iowa Code ANN. c. 600, $\$ \$ 1-8$ (1950), Minn. Laws 1917, c. 222, repealed and superseded by Mrns. Stat. ANN. c. 259 , $\$ \$ 21$ 32 (West Supp. 1953); N.J. Laws 1902 , c. $92, \$ \$ 1-5$, repealed and superseded by N.J. STAT. ANN. tit. 9, c. 3, $\$ \$ 1-36$ (Supp. 1953); N.C. Pub. Laws 1941, c. 281, as amended, N.C. Gen. Stat. c. 48 (1949).

22. See Cox, Pennsylvania's Need-An Adequate Protective Adoption Program, 22 PA. BAR Ass'N Q. 154, 158 (1951).

23. Pa. Laws 1855 , No. 456 , p. 430.

24. Pa. Laws 1872, No. 20, p. 31.

25. See Pa. Dep't of Welfare, The 1953 Adoption Amendment on file, Biddle Law Library, University of Pennsylvania Law School. 1953).

26. Pa. Laws 1925, No. 93, p. 127; PA. Stat. Ann. tit. 1, $\$ 1$ et seq. (Purdon

27. See text at notes 17-9 supra. This statute did allow the court, at its option, to have an investigation of the adoptive home made at the time of the hearing on the adoption petition; this optional investigation is also available under the new act.

28. Total adoptions in Pennsylvania from 1944-51, taken from statistics on file with Children's Aid Society of Pennsylvania, 311 S. Juniper Street, Philadelphia, Pa.: 1944-2962; 1946-3504; 1947-3639; 1948-4107; 1949-4108; 1950-3860; $1951-4216$.

29. Pa. Stat. Ann. tit. 1, §1 et seq. (Purdon Supp. 1953).

30. See Jones, Pennsylvania's Adoption Law in Action, Currents IN PenNsylvania Healte and Welfare 9 (Pennsylvania Citizens Association, Spring 1954). Mrs. Jones is Deputy Secretary of the Pennsylvania Department of Welfare. See also text at note 16 supra.

31. See text at notes 47,48 infra. 
the adoption petition. ${ }^{32}$ The courts may grant decrees transferring custody and the right to consent from natural parents to agencies approved by the State Department of Welfare. This gives the parents an opportunity to consult the agency's qualified staff before surrendering the child, and if the child is surrendered to the agency, the parent does not appear again in the adoption proceedings. ${ }^{33}$ Where under the act's definition of abandonment the child has been abandoned for at least six months, the courts are also authorized to grant custody of a child and the right to consent to his adoption to an approved agency ${ }^{34}$ this makes it impossible to release for adoption some formerly unadoptable children. ${ }^{35}$ Approved adoption agencies are an important part of the new Pennsylvania adoption procedure and special provision has been made for approval of such agencies by the State Department of Welfare. ${ }^{36}$ The more important provisions of the Pennsylvania act, as an example of recent adoption statutes, will bear analysis to determine to what extent the current enactments further the modern goals of adoption legislation.

\section{The Placement Process}

Adoption is a twofold procedure. The first phase is the placement process by which a child is placed in the adoptive home. Generally he must live in the prospective adoptive home for a considerable period of time, in many states for a minimum of six months. ${ }^{37}$ After this period has elapsed, the second or legal phase of adoption is instituted. First a petition for adoption is filed, in Pennsylvania with the Orphans Court. Subsequently there is a hearing on the petition at which the court determines whether the proper consent has been given, or in lieu thereof whether there has been abandonment or whether some other condition exists waiving the need for consent, ${ }^{38}$ and whether the adoption is in the best interests of the child. These issues have been determined in the affirmative, a decree of adoption is entered, final in some states and in others interlocutory for an additional period..$^{39}$

32. See text following note 85 infra.

33. Ibid.

34. See text at note 103 infra.

35. See Jones, supra note 30 .

36. See text at note 145 infra.

37. See, e.g., Minn. Stat. Ann. c. 259, §27 (West Supp. 1953) ; N.Y. Domestic Relatrons Law \$112(7); PA. Stat. ANN. tit. 1, \$4 (Purdon Supp. 1953) (prior act) ; TEx. Crv. STAt. ANN. art. 46a, \$ 3 (Vernon 1953) (may request waiver of six months period); Wyo. Comp. Stat. ANN. c. $58, \$ 209$ (1951). In some jurisdictions the period before final decree of adoption is longer. See, e.g., 39 Iowa CodE ANn. c. $600, \$ 2$ (1953) (one year) ; N.C. GEN. STAT. c. 48, \$\$17-21 (1953) (one year); N.

DAK. Rev. Code tit. 14, c. 11, \$1116 (Supp. 1953) (two years); 5 OHIO GEN. CoDE ANN. $\$ \S 8004.9-8004.11$ (Page Supp. 1952) (one year); VA. CoDE tit. 63, §356 (1952) (one year).

38. Where the natural parent is of unsound mind, or is a habitual drunkard, consent is not normally required. See MinN. Stat. ANN. c. 259, $\$ 03$ (West Supp. 1953); N.Y. Domestic Relations Law $\$ 111(4)$; PA. Stat. Ann. tit. 1, \$2 (Purdon 1953) (prior law). For other situations where consent is not required, see Note, 24 Rocky Mr. L. Rev. 357, 362 (1952).

39. See statutes in note 37 supra. 
There are generally two types of placement: agency and individual. Problems are most likely to be created when the latter method is used; in fact, individual placement, or the gray market, as it is called, is perhaps the most serious problem in adoption. ${ }^{40}$ In the typical agency placement, a detailed study is made by the agency of the child's background and its health and mental capacities. In addition, the prospective home is carefully scrutinized in order to determine whether the prospective parents are mentally, morally, economically and psychologically fit to assume the care of the particular child. It is only after these studies have been made and the results found to be favorable that the child is placed in the adoptive home. ${ }^{41}$ Where a child is placed by individuals, however, and such has been the case in $48 \%$ of non-relative adoptions, ${ }^{42}$ there is frequently little investigation made as to the suitability of the child or the adoptive home. More often than not, a well meaning physician, minister or attorney takes the child of an unwed mother and, with no more than a superficial examination of the suitability of the adoption, consigns it to the care of persons he knows are desirous of adopting a child. ${ }^{43}$ At the subsequent hearing on the adoption petition, the court, in an effort to determine whether the adoption is in the best interests of the child, may order an investigation which might show the child or the adoptive home to be unsuitable in some particular. ${ }^{44}$ Then the court is faced with a dilemma. Although the child or home is unsuitable in some respect, the child by virtue of his having been in the adoptive home for a considerable period of time has formed emotional attachments to the adoptive parents and conversely they to him. Psychologists recognize that uprooting the child under such circumstances might have serious emotional repercussions. ${ }^{45}$ The realization of this

40. See Note, 59 Y ALE L.J. 715 et seq. (1951) and authorities cited therein. Conversely, the black market problem of dealing commercially in children is no longer considered to be of major significance. See BowlBY, MATERNAL CARE AND Mental Healte, World Health Organization: Monograph Series 107 (1952). This option is also expressed by the Yale Law Journal after conducting a survey of various states. See Note, 59 Y ALE L.J. 715 n.2 (1950).

41. Information received from conversation with Mr. Walter $P$. Townsend, General Secretary of the Children's Aid Society of Pennsylvania, Philadelphia Bureau. A more detailed presentation of the agency procedure can be found in Note, 59 Y ALE L.J. 715 (1950). See also Clothier, Placing the Child for Adoption, 26 Mental Hygiene 257 (1942)

42. Children's Bureau Statistical Ser., op. cit. supra note 20, at 5 . These are the latest available figures. See note 20 supra.

43. The incidence of unsuitability in independent placement as opposed to agency placement is illustrated by a study conducted in 1945 by Dr. Catherine S. Amatruda of the Yale Child Development Clinic, the results of which are cited in the Yale Law Journal. "Her standards were modest. A child was regarded as a good adoption risk unless it was mentally retarded or had serious personality defects. A family was regarded as suitable unless the investigation disclosed a highly unstable marriage, serious psychiatric difficulties, alcoholism, prostitution, wife beating, or drug addiction. Of the hundred independent placements, only 46 were satisfactory; 26 were questionable at best; and 28 were definitely undesirable. The hundred agency placements, on the other hand, had brought about a satisfactory situation in 76 instances; a questionable situation in 16; and an undesirable situation in only 8." Note, 59 Y ALE L.J. 715, 124 n.43 (1950).

44. See note 19 supra.

45. See Bowlby, op. cit. supra note 40; Colby, Protection of Children in Adoption, 65 Proceedings of the National Conference of Soctal Work 146, 154 (1939). 
exerts a pressure on judges to approve the adoption despite the unsuitability of the adoptive home.46

In an effort to solve this problem, the Pennsylvania legislature has enacted Section 1(c) of the new act. This section provides that every person receiving possession or control of a child for the purpose or with the intention of adoption has the duty to make a report to the court of the county wherein such person resides within thirty days of receiving possession or control of the child; this report must name the intermediary from whom the child was received. ${ }^{47}$ Thereupon the court is required to cause a complete investigation to be made as to the suitability of the placement, by an appropriate person. ${ }^{48}$ Natural parents, grandparents, step-parents, brothers or sisters of the whole or half blood and uncles or aunts by blood or marriage are specifically excluded from the requirement of making a report. Where the child has been received from an agency, the court may accept a report from that agency in lieu of an investigation. The provision does not outlaw independent placements, since there are not enough qualified agencies available to give the necessary service. Any such prohibition will therefore not be workable until existing agency services are strengthened and new ones developed. ${ }^{49}$ The Pennsylvania provision does, however, attempt to remedy the danger inherent in an independent placement, by providing for an examination of the suitability of the home and the child for each other before any deep attachment has been formed.

Section 1(c) represents one of several legislative approaches to the independent placement problem. Statutes in some jurisdictions provide that no person except a natural parent, a guardian, a relative or an authorized agency may place a child for adoption. ${ }^{50}$ However, the effectiveness of this type of provision is reduced by the fact that a third party can influence a natural parent to place the child for adoption. Moreover, even

46. In 1938 it was stated that only $16 \%$ of adoption petitions where the adoptive home was found to be unsuitable were dimissed or denied. Colby, supra note 45 , at 156. For judicial discussion of the emotional disturbance factor see, e.g., Pool v. Gott, 14 L. Rep. 269 (Mass. 1851) ; Commonwealth ext rel. Children's Aid Society v. Gard, 362 Pa. 85, 90, 66 A.2d 300, 303 (1949); Davies Adoption Case, 353 Pa. $579,588,46$ A.2d 252, 257 (1946). In the Davies case the court said, "The emotional disturbance to a child that would threaten from its being removed summarily and permanently from familiar and agreeable surroundings and associations, incident to the only parental control and supervision it has ever known, could have a very harmful effect on the child's whole life. Fortunately, the law's regard for a child's welfare does not admit of any such injury or harm being done it." Id. at 588, 46 A.2d at 257.

47. The report shall also contain the circumstances surrounding such person's receiving or retaining possession of the child plus name, age, date and place of birth, and religious affiliations of the child and persons making the report.

48. "Such investigation shall include pertinent information with regard to the health antecedents and eligibility for adoption of the child, the health, social and eonomic status of the adopting parents and any other information regarding the suitability of the placement." PA. STAT. ANN. tit. 1, \$1(c) (Purdon Supp. 1953).

49. Letter dated April 6, 1954 from Mr. Walter P. Townsend, General Secretary, Children's Aid Society of Pennsylvania, Philadephia Bureau, on file, Biddle Law Library, University of Pennsylvania Law School.

50. See, e.g., WIS. Stat. c. 48, \&37(1) (1951); D.C. Code tit. 32, §705 (1951); N.Y. Social Welfare Law $\S 374$. 
without influence of third persons, direct placement by natural parents, guardians or relatives is no guarantee of the suitability of the adoption. ${ }^{51}$ Several states require that no placement may be made without a court order or the consent of the welfare department, ${ }^{52}$ but in these statutes there are no provisions for investigation; in addition, experience with one such statute has shown widespread violation. ${ }^{53}$ The Pennsylvania provision falls into a third category, i.e., statutes requiring that persons receiving or placing children in adoptive homes must file a report, and thereafter submit to an investigation. ${ }^{54}$ As long as some independent placements must be permitted, this last class of provisions, properly administered, is perhaps the best solution to the problem of independent placements.55 However, the specific provisions of the Pennsylvania section contain several weaknesses.

One difficulty with the Pennsylvania provision lies in the fact that it provides no sanction for failure to file a report. While it has been suggested that a failure to file might preclude an adoption decree from being granted, ${ }^{\text {n6 }}$ it is doubtful that this result would occur frequently. The fact that no report has been filed and consequently no investigation made will normally become known only at the time of the hearing on the adoption petition, which will be at least six months after placement. If investigation at that time shows the adoptive home to be suitable, there would be little reason to deny the decree. If, on the other hand, the home is found to be unsuitable, the court will be faced with the same dilemma which existed before the new provision was enacted: whether to risk severe emotional disturbance to the child by uprooting him ${ }^{57}$ or to allow him to remain in an unsuitable home. There is nothing to indicate that the courts will be more inclined than previously to decide to remove the child.

51. Examples of the operation of this procedure are given in an opinion by the attorney general of Wisconsin cited in Note, 59 Y ALE L.J. 715, 732 n.91 (1950). "The physician who confined Miss $A$, an un-married mother, learned that she had expressed a wish to place her child for adoption. He therefore informed $\mathrm{Mr}$. and Mrs. Y, who were patients of his, that he knew of a child that would be available for adoption. He gave the name of the adoptive parents to the mother. They made arrangements to transfer the child to them upon discharge from the hospital. The adoptive parents sent a relative to meet the mother outside the hospital and the relative transported the child alone to the prospective adoptive home." The attorney general also expressed a reluctance to prosecute the doctor in such a situation. "... [I]t is our opinion that on the narrow fact situation presented no successful prosecution could be maintained."

52. See, e.g., Mo. Rev. STAT. ANN. $\$ 453.110$ (Vernon Supp. 1953) (court order); Neb. Laws 1949, c. 204, § I (court order); OHro GeN. Code ANN. \$1352-13 (1946) (consent of the welfare department or court order, for children under two years).

53. Mullenix, Ohio Adoption Study 28-30, 38-9, 42, 178 (mimeo 1941).

54. See also, e.g., Mp. ANN. Code GEN. LAws art. 88 A, §16A (Flack Supp. 1947) (receivers must notify welfare department); MAss. ANN. LAws, c. $119 \$ 14$ (Supp. 1948) (placers and receivers); N.H. Rev. LAws c. 130, \$17-8 (1942) (receivers); R.I. GEN. LAwS ANN. c. 373, \$3 (1938) (placers). However, unlike Pennsylvania, in Massachusetts, Maryland and New Hampshire the investigation is discretionary with the department.

55. See text at note 49 supra.

56. See Busser, The Adoption Act of 1953, 25 PA. BAR Ass'N Q. 197 (1954).

57. See note 46 supra. 
An adequate sanction is essential if the report and investigation provision is to be effective. Perhaps the most effective sanction would be a positive pronouncement in the act that a failure to file would result in the child's being removed from the adoptive home. Yet, such a provision would lead to the removal of some children from suitable homes-an undesirable result no matter what the reason for the tailure to file. An alternative sanction would be a heavy fine for failure to file. ${ }^{58}$ Although a wealthy adoptive parent may not be affected by this sanction, to the majority of adoptive parents the fine would be a strong incentive to file. ${ }^{50}$ More important, the threat of a fine would tend to deter placements with prospective parents who suspected that they did not meet the stautory requirements and were therefore anxious to avoid investigation. Adding the knowledge that a heavy fine must be paid to the risk of losing the child on the ground of unsuitability, which risk is never completely absent, would operate to reduce the likelihood of such persons' accepting a child.

Aside from the question of sanction there is another major difficulty with section 1 (c) as presently framed. The section requires that only persons who have possession or control of a child "for the purpose or with the intention of adopting such child . . . need file a report." 60 Many persons who eventually adopt children receive them initially for what they believe to be only a temporary period, with no intention to adopt.61 If the child lives for a long period of time with the family and forms strong attachments before a report is filed, the investigation process may come too late to be effective. The danger involved in requiring that only persons who have an intent to adopt need file a report might be reduced in several ways. Under the provision as framed, a burden of proving no intent at time of receipt should be placed on the parents petitioning for adoption. Alternatively, the intent to adopt language might be deleted and the provision made to require that "whoever receives and whoever places an infant . . . for adoption or for giving it a home or for procuring a home or adoption for it" ${ }^{82}$ must file a report. Even so broad a provision would not require filing for a considerable period of time after receipt of a child in instances where there is no intent to give the child a home. Extending the filing provision to placements intended to be temporary, however, would give such broad coverage as to create problems

58. Cf. N.H. REv. Laws c. $130, \$ 15$ (1942) (provides for $\$ 100$ fine or one year imprisonment). See also KY. REv. STAT. c. 199, §350 (1953) (person bringing child into state to place for adoption must file $\$ 10,000$ bond conditioned, inter alia, on filing a report with Welfare Department).

59. Of 281 applications for adoption filed with the Children's Aid Society of Pennsylvania, very few represented persons with incomes over $\$ 8000 ; 133$ applicants had incomes between $\$ 3000$ and $\$ 5000$. Information received from Children's Aid Society of Pennsylvania, Philadelphia Bureau, 311 Juniper St., Philadelphia.

60. Pa. Stat. Ann. tit. 1, §1(c) (Purdon Supp. 1953).

61. This factor was pointed out by Hon. Edward Leroy van Roden, President Judge of the Orphans Court in Delaware County, Pa.

62. 4 MASS. ANN. Laws c. 119, \$14 (1949). Under this statute apparently even relatives must report receipt of a child; but compare 4 MAss. ANN. LAWs c. 119, $\$ 6$ (1949). See discussion of relative adoptions at note 64 infra. 
of enforcement and administrative feasibility. Welfare departments today cannot, and probably would not want to, check up on every child visiting friends for any substantial length of time. ${ }^{63}$ Obviously, any filing requirement depends for effectiveness on enforceability and availability of sufficient investigatory facilities to take advantage of the filed reports.

In addition to the foregoing there are other deficiencies which to a greater or lesser extent reduce the effectiveness of the Pennsylvania provision for a report and investigation on receipt of the child. Several classes of relatives are excluded from the filing requirement. It has been suggested that these groups might also be unsuitable to rear the child and should submit to investigation before the child has been placed in their home. ${ }^{64}$ At least two arguments serve to justify the exclusion of some relatives. First, a great number of relative-adoptions are by a step-parent and his or her individual unsuitabiility would make little difference, since the child would normally be living with that parent in any event. ${ }^{65}$ Furthermore, insofar as the statutory provision is meant to protect an adoptive parent from forming an attachment for a child who later proves to be in some way retarded or afflicted, the exclusion is justified since relatives are more likely to be aware of the child's background. While these arguments carry some weight they do not overcome the harm which can occur from an unsuitable placement with relatives, which might be avoided by timely investigation. It has been suggested that the exclusion was enacted as a result of strong "social policy" against interference in intra-family relations in this area. ${ }^{68}$ It would appear, however, that the influence of any such policy is diminishing, in view of the several areas in which intra-family relations have become subject to state regulation. ${ }^{67}$ Moreover, even assuming strong community opposition to interference with family adoptions, a tactful

63. New Hampshire, however, has such a requirement. N.H. Rev. LAws c. $130, \S 12$ (1942) provides: "Whoever receives [a child] under his care or control . . for a period of more than 30 days shall within two days [after receiving it] give notice thereof and of the terms upon which such infant was received, to the commissioners of public welfare. . . " Relatives are excluded from this provision but, as written, schools, camps, and other institutions would appear to be covered.

64. See Children's Bureau Pub., op. cit. supra note 16, at 17. Some judges have expressed to the writer an intention to require an investigation of members of the excluded class at the time of the adoption hearing, under the authority of Section 3 of the new Act which provides that at the time of the adoption hearing the court "shall also make or cause to be made an investigation . . . to verify the statements of the petition and such other facts as will give the court full knowledge as to the desirability of the proposed adoption."

$65.39 \%$ of all adoptions for which a family relationship was reported were by step-parents. See Children's Bureau Statistical Ser. No. 14, p. 4, table 3 (Dep't Health, Educ. and Welfare 1951).

66. Opinion expressed by Mr. Ralph C. Busser, Jr., Chairman, Committee on Family Law, Pennsylvania Bar Association; also by Mr. Walter P. Townsend, General Secretary, Children's Aid Society of Pennsylvania, Philadelphia Bureau.

67. See, e.g., Uniform Recifrocal Enforcement of Support Act, 9(A) ULA 57 (Supp. 1953), PA. Stat. Ann. tit. 62, $\$ \$ 2043.1-2043.27$ (Purdon Supp. 1953) (provides method of getting support from father or husband outside jurisdiction without suing in foreign jurisdiction or bringing respondent into petitioner's jurisdiction) ; Juvenile Court Law, PA. Star. ANN. tit. 11, $\$ 243$ et seq. (Purdon 1953) (neglected children can be removed from parental home). 
approach by investigators, and the indulgence of an almost inescapable presumption that because of the nature of the family tie a relative home is suitable, should help to overcome any antagonism.

There are two other deficiencies in the Pennsylvania filing provision which warrant consideration. First, the section makes no provision for the child if the adoptive home is found to be unsuitable. ${ }^{88}$ While judges might have the child turned over to an institution, it is possible that without a legislative recommendation to this effect courts may be inclined to find the home suitable rather than to institutionalize the child. ${ }^{69}$ In the second place, an inexperienced investigator might be appointed. The provision for investigation states that the investigation be made by a child care agency (with its consent if it is a private agency) or by the State Welfare Department. However, in lieu of either of these alternatives, the court may appoint any appropriate person to make the investigation. ${ }^{70}$ There is a danger that such an appointee might lack the necessary qualifications. To be effective, the examination requires more than a mere finding of the child's and adoptive parents' good health and a determination that the latter are capable of supporting the child. The motivation underlying the desire to adopt a child is vital, and elements such as the emotional stability of the adoptive parents are not to be underestimated. ${ }^{\mathbf{7 1}}$ The court should exercise great care in appointing investigators, and it is unfortunate that the legislature has not created at least minimum criteria to govern the choice. ${ }^{72}$ With or without minimum criteria, however, finding sufficient qualified investigators will be a problem. Individual investigators must continue to be used, since currently existing public and private agencies are already hardpressed to make adequate investigations before the child is settled in the adoptive home. ${ }^{73}$ In placement investigation, as in all phases of adoption, real advancement depends upon public recognition of the problem and support of adequate public facilities. ${ }^{74}$

68. Under the Massachusetts statute the Department of Public Welfare may take the infant into custody if the protection of the infant so requires. 4 MAss. ANN. LAws c. $119, \S 14$ (1953). In New Hampshire the court can make orders for the custody, care or protection of the child. N.H. Rev. Laws c. $130, \S 14$ (1942).

69. Especially is this true in view of the growing emphasis on avoiding lengthy placement in institutions and boarding homes. CHIIDREN'S BUREAU STATISTICAI. SER., op. cit. supra note 20 , at 1 .

70. ". . the court shall cause a complete investigation to be made by one of the following agents, a local public child care agency, a private child care agency (with its consent), the State Department of Welfare, an appropriate person designated by the court. ..." PA. Stat. ANN. tit. 1, §1(c) (Purdon Supp. 1953).

71. See Children's Bureau Pub., op. cit. supra note 64, at 17; Note, 59 Yale L.J. 715, 720 (1951); BowLBY, op. cit. supra note 40, at 104-5.

72. Other jurisdictions allowing the court to appoint investigators also fail to establish minimum criteria. See ILL. ANN. STAT. c. 4, §3-1 (Smith-Hurd Supp. 1949) ("suitable person"); S.D. CoDE $\$ 14.0406$ (1953) ("discreet and competent person"). See also Note, 59 Yale L.J. 715, 730 n.80 (1950).

73. In Rhode Island, a state having a provision similar to Pennsylvania's investigation requirement, as of 1949 the case-load was reported as 200 investigations per worker. See Note, 59 Yale L.J. 715, 734 n.101 (1950).

74. See text at note 163 and note 163 infra. 


\section{The Legal Phase}

\section{A. Voluntary Relinquishment}

The problem of consummating an adoption satisfactory for the child, natural parents and adoptive parents is complicated by difficulties arising not only out of the placement procedure, but from the legal phase of adoption as well. Practically every state requires, absent certain situations which are deemed tantamount to consent, ${ }^{75}$ that the consent of the natural parent or parents to adoption be obtained before an adoption decree is entered. ${ }^{76}$ In the majority of jurisdictions the consent issue does not arise until the time of the hearing on the adoption petition, ${ }^{77}$ which fact can give rise to serious problems. It is agreed that it is best for all parties if the natural parent does not know the identity of the adoptive parents, ${ }^{78}$ yet this identity is revealed through the appearance, for consent purposes, of the natural parents at the hearing. There is an even more important difficulty with many consent practices. Children, especially illegitimate children, ${ }^{79}$ are often placed for adoption after a hasty decision on the part of the natural parent, motivated by family pressure or real or imagined fear of social stigma. ${ }^{80}$ Furthermore, consent may be obtained through fraud. ${ }^{81}$ At the subsequent hearing on the adoption petition or on appeal, the natural parent may contest the adoption on the ground that no proper consent was given, and the adoption decree may be denied or vacated. ${ }^{82}$ Denial of the decree does not automatically determine custody, however; this is a further determination which must be made after the denial of the

\section{See note 38 supra.}

76. A complete listing of consent provisions is found in Note, 24 Rocky Mr. L. REv. 359, 360 n.18 (1952). Apparently South Carolina has no provision requiring consent of the natural parent or parents. See S.C. Cone $\$ 10-2581$ et seq. (1953).

77. But cf. DeL. Code AnN. tit. 13, \$\$1101-9 (1953); Wis. Stat. c. 48, $\$ 07(7)(a)(Y)(c)$ (1951) (these statutes provide for termination of parental rights prior to the time of the adoption hearing).

78. Bowlby, op. cit. supra note 40, at 106. Cf. Children's Bureau Pub., op. cit. supra note 16 , at 8 (recommending that there should be a prior termination of parental rights to prevent the natural parents from gaining knowledge of the identity of the adoptive parents).

79. Half of the children for whom adoption petitions are filed were born out of wedlock. ChildRen's BUREau Statistical SER., op. cit. supra note 20, at 7.

80. See, e.g., Susko Adoption Case, 363 Pa. 78, 69 A.2d 132 (1949); Deama Adoption Case, 165 Pa. Super. 12, 67 A.2d 751 (1929); Combs v. Edmiston, 216 Ark. 270, 225 S.W.2d 26 (1949).

81. See, e.g., Falck v. Chadwick, 190 Md. 461, 59 A.2d 187 (1948)' (parent thought adoption was merely prcvisional) ; Lambert v. Taylor, 150 Fla. 680,8 So.2d 393 (1942) (mother signed consent thinking it was merely to give child name); Arnold v. Howell, 98 Cal. App.2d 202, 219 P.2d 854 (1950) (parent thought adoption was only temporary).

82. See, e.g., Susko Adoption Case, 363 Pa. 78, 69 A.2d 132 (1949); Lambert v. Taylor, 150 Fla. 680,8 So.2d 393 (1942); Skaggs v. Gannon, 293 Ky. 795, 170 S.W.2d 12 (1943); Combs v. Edmiston, 216 Ark. 270, 225 S.W.2d 26 (1949). 
petition, on the basis of the child's best interests. ${ }^{83}$. If custody is awarded to the natural parent, the child and adoptive parents are injured by the abrupt dissolution of an attachment which may have been welded over a considerable period of time. ${ }^{84}$ Conversely, if the court awards custody to the adoptive parents, the natural parent may be made to suffer unduly for a hasty decision to relinquish the child. ${ }^{85}$

The Pennsylvania legislature has attempted to alleviate this problem by a provision for voluntary relinquishment. Section 1.1 of the new act provides that when a person under eighteen years of age has been in the care of an approved agency for at least thirty days, the parent or parents may petition the court for permission to relinquish forever all parental rights, and the agency shall join in such petition. After a hearing in which the court decides the truth of the averments, a decree is issued directing transfer of custody to the agency and authorizing such agency to consent to a subsequent adoption without further consent of or notification to the parents. This provision goes a long way toward resolving the difficulties under the prior law. In many cases where placement has been by an agency, ${ }^{86}$ the court will be able to determine consent judicially before the child is placed in an adoptive home; therefore it can effectively prevent placement under an improper consent and subsequently, when determining whether the adoption is in the best interest of the child, ${ }^{87}$ it will not be faced with the choice between a defrauded or coerced natural parent and a devoted foster parent. ${ }^{88}$ In addition, since the natural parent may consent before the child is placed for adoption and need not later be informed of the adoption hearing, the adoptive parents need no longer fear subsequent contacts with the natural parent. Since under the voluntary relinquishment provision custody of the child and authority to consent to a subsequent adoption is awarded to the agency, there is the additional benefit that the agency can perform its task of placing the child with more assurance

83. See Oelberman Adoption Case, $167 \mathrm{~Pa}$. Super. 407, 74 A.2d 790 (1950); Petition of Sulewski, 113 Pa. Super. 301, 173 Atl. 747 (1934). Cf. Urrutia v. Urrutia, 142 S.W.2d 267 (Tex. 1940); Strode v. Silverman, 209 S.W.2d 415 (Tex. 1948). In re Adoption of Mary Alice Miller, 98 Pitt. Legal J. 105 ( $\mathrm{Pa} .1950)$; Lambert v. Taylor, 150 Fla. 680,8 So.2d 393 (1942).

84. In the Lambert case, note 83 supra, child was in foster home for seven years before removal.

85. In the Miller case, note 83 supra, the court awarded custody to the adoptive parents temporarily. In determinations like this, both parties would suffer: the natural parent until she can recover the child, the adoptive parents since they may have to relinquish the child, and the child since he still may be uprooted.

86. This procedure may not be available where there is an independent placement. See text at note 90 infra.

87. See text following note 110 infra.

88. In Wisconsin and Delaware, states having a similar provision for prior termination of parental rights (see note 77 supra), there has been no record of adoption petitions contested on the ground of improper consent. See communication to this effect from Mr. Fred DelliQuadri, Director, Wisconsin State Welfare Dep't, Division for Children and Youth, Jan. 19, 1954, and Mrs. Jerry T. Ross, Supervisor of Adoptions, Delaware Dep't of Welfare, Jan. 11, 1954, on file, Biddle Law Library, University of Pennsylvania Law School. 
of permanency to prospective parents. This furthers the whole adoption process. ${ }^{89}$

However, there is one major difficulty which the section does not resolve. No provision is made for termination of parental rights prior to the adoption hearing where a child has been placed by the natural parent or an individual intermediary. ${ }^{90}$ In these situations the adoptive parents are still subject to harassment by the natural parent and decrees may still be contested for improper consent. Furthermore, the typical consent contest in the past has arisen where an individual intermediary or an independent placement was involved. ${ }^{91}$ The argument has been made that since prior termination also involves an award of custody to the intermediary, and since individual intermediaries are not in a position to care for the child properly prior to placement, termination should be allowed only where an agency is involved.92 However, the natural parent should be able to relinquish his rights to a child whether or not the child is presently in the control of an adoption agency. Where an independent placement is involved, the court after termination of parental rights could award custody of the child to the Department of Welfare or an approved agency as it sees fit..$^{33}$

The voluntary relinquishment provision is also deficient in failing to provide a time limit on appeals from a decision terminating right to custody. Limitation of the right to appeal is important since as long as an appeal is possible, it is better not to place the child. The general Pennsylvania appeal provision, applicable here, enables appeals to be taken within three months after the entry of the order. ${ }^{94} \mathrm{~A}$ shorter limit, like the Wisconsin provision of forty days, ${ }^{95}$ would be preferable. With such a limit the child would probably not be placed before an appeal is taken, or at

89. Opinion expressed by Mr. Walter P. Townsend, General Secretary, Children's Aid Society of Pennsylvania, Philadelphia Bureau.

90. Section 1.1 provides for termination of parental rights where "any person . . has been in the care of an approved agency. . " (italics added). PA. DEP'T of Welfare, The 1953 Adoption AMENDMENT 9 (1953).

91. See cases cited in notes 80-83 supra. Unlike Pennsylvania, the Missouri and Delaware provisions do not require that the child be placed with an approved agency before termination of parental rights is allowed. See provisions cited in note 77 supra.

92. Opinions expressed by Hon. Edward Leroy van Roden, President Judge of the Orphans Court of Delaware County, Pa.; Mr. Walter P. Townsend, General Secretary, Children's Aid Society of Pennsylvania, Philadelphia Bureau, Ralph C. Busser, Jr., Chairman, Committee on Family Law, Pennsylvania Bar Association.

93. The Delaware voluntary termination provision provides that whenever the natural parents desire to relinquish custody or parental rights,

". . The Orphans' Court having jurisdiction of the proceedings may terminate all existing rights of the parent or parents, person or agency then having such rights with reference to such child, and may grant such rights to such person or authorized agency or the Department of Public Welfare as may seek them, or to such person or authorized agency or the Department of Public Welfare as may, in the opinion of the court, be best qualified to have them." Del. Code ANN. c. 13, \$1103 (1953).

94. Pa. Stat. Ann. tit. 12, §1136 (Purdon 1953).

95. WIS. Stat. $\$ 48.07(8)$ (1953). 
least placed only for a short time. Under the Pennsylvania law a court hearing an appeal might still be faced with the dilemma of uprooting the child or working a hardship on the natural parent.

\section{B. Abandonment}

Another issue in the legal phase of the adoption procedure which can work severe hardship on the parties involved is the problem of abandonment. Under many statutes, where abandonment is found the consent of the natural parent to adoption is not required. ${ }^{8 B}$ Like the consent issue, however, the question of abandonment is frequently not resolved until the time of the hearing on the adoption petition. ${ }^{97}$ Problems similar to those raised by the consent requirement may therefore result. A child apparently neglected by its natural parent or parents might reside in a foster home for a considerable period of time, but at the time of the adoption hearing or even subsequently it might be determined that no abandonment had occurred and the decree denied or vacated. ${ }^{98}$ A finding of no abandonment is especially likely under the stringent requirements of many abandonment doctrines which demand a settled intent to forego the parental. relationship, ${ }^{93}$ and in some cases demand the element of wilfulness. ${ }^{100}$ Where the court at the adoption hearing finds no abandonment, it may still be confronted with the necessity of deciding the issue of custody between devoted foster parents to whom the child is strongly attached and a natural parent who has not legally abandoned his child and whose absence may have been justified. ${ }^{101}$ Even if the foster parents receive custody, "legal title" and claims to the child's filial obligation remain

96. See, e.g., MD. Rev. Stat. art. 16, $\$ 85(G)$ (1947) ; Pa. Stat. Ann. tit. $1, \S 2$ (C) (Purdon 1953); DEI. CODE ANN. tit. 13, §908 (1951). See generally, 4 VERNIER. AMERICAN FAMILY Laws 340 (1936).

97. See, e.g., Weinbach's Appeal, 316 Pa. 333, 175 Atl. 500 (1934); Smith v. Crivello, 338 Ill. App. 503, 88 N.E.2d 107 (1949); In re Anonymous, 195 Misc. 6 88 N.Y.S.2d 829 (Surr. Ct. 1949).

98. See, e.g., Schwab Adoption Case, 355 Pa. 534, 50 A.2d 504 (1947) (mother visited child three times in year and half, no abandonment); Adoption of Nora Espenshade, 55 Dauph. County $399(\mathrm{~Pa} .1945)$ (father gave gifts, visited from time to time, child "at adopting parents" home for 11 years, no abandonment) ; Crawford v. Arends, 351 Mo. 1100, 176 S.W.2d 1 (1943) (defect in decree 17 years later for purposes of inheritance); People ex rel. Cocuzza v. Cobb, 196 Misc. 961, 94 N.Y.S.2d 616 (Sup. Ct. 1950) (child in adoptive home for 6 years, no abandonment).

99. See tests used in Oelberman Adoption Case, $167 \mathrm{~Pa}$. Super. 407, 74 A.2d 790 (1950); McGill's Adoption, 49 Pa. D. \& C. 374 (1944); Winans v. Luppie, 47 N.J. Eq. 302, 20 Atl. 969 (Ct. Err. \& App. 1890).

100. In re Gates' Adoption, 84 Ohio App. 269, 85 N.E.2d 597 (1948) (although found failure to provide home, food, clothing, absence of allegation of wilful conduct allowed parents to prevent adoption). Cf. Adoption of Joseph David Taxter, 51 Montg. County 18 ( $\mathrm{Pa}$. 1933).

101. See, e.g., Susko Adoption Case, $363 \mathrm{~Pa} .78,69$ A.2d 132 (1949) (mother's failure to keep illegitimate child with her was occasioned by family pressure) ; Molin Adoption Case, 34 Del. County 470 ( $\mathrm{Pa} .1946$ ) (mother ill and father in the service); Ashton Adoption Case, $374 \mathrm{~Pa}$. 185, 97 A.2d 368 (1953) (mother never saw child, information of its whereabouts kept from her). 
with the natural parent. ${ }^{102}$ While the adoptive parents may have assumed all financial and other parental responsibilities, the natural parents may continue to show just enough interest in the child to preclude adoption.

Section 1.2 of the new Pennsylvania statute attempts to meet these difficulties by providing that when a person under the age of eighteen years has been in the care of an approved agency for a minimum of thirty days and it appears that such person has been abandoned for at least six months, the agency may petition the court for a hearing to find abandonment and award custody to the agency. Five days' notice by registered mail is given to the alleged abandoning parents. Subsequently, the hearing takes place and, after a finding of abandonment, custody is awarded to the agency along with the authority to consent to a subsequent adoption. ${ }^{103}$ Providing in this fashion for a determination of the issue of abandonment before the child is placed for adoption removes, to some extent, the dangers involved in the prior practice. Adoptive parents need no longer worry about the denial of their petition on this, ground, and judges will not have to face the necessity of choosing between a worthy adoptive parent and a natural parent whose neglect has been justified.104 However, just as with the voluntary relinquishment provision, prior judicial determination of abandonment can occur in Pennsylvania only where the child is in the care of an approved agency. In the great many cases where no agency is involved, ${ }^{105}$ the disadvantages of delayed determination of abandonment remain. It should be provided that persons receiving children from independent placements might, when it appears that there has been abandonment, file a petition for a determination as to abandonment: The determination could be made, as it is in the case of agency placements, without waiting for the hearing on the adoption petition, and, if abandonment is found, an award of custody could be made to the new parents, with the right to consent to a subsequent adoption given to the Welfare Department. While it is impossible in the case of an independent placement to provide for an abandonment determination before the placement has been made, it is desirable to settle the issue as early as possible, so that the prospective adoptive parents will know whether or not the child will be adoptable and can adjust their relationship to the child accordingly.

The abandonment question involves not only the question of securing an early determination of the abandonment issue, but also the danger of making children unadoptable as a result of too stringent definition of abandonment. The Pennsylvania act incorporates the definition of abandon-

102. Custody is only one of the parent's rights. Deprivation of this right does not necessarily terminate natural parents' survivorship rights, rights to earnings, or child's duty to support parents. For a complete analysis of reciprocal rights and duties between parent and child, see 4 VERNIER, AMIERICAN FAMILY LAwS 4 et seq. (1936).

103. Pa. Stat. Ann. tit. $1, \S 1.2$ (Purdon Supp. 1953).

104. See cases cited note 101 supra.

105. See text at note 42 supra. 
ment commonly applied under prior practice, "conduct on the part of a parent which evidences a settled purpose of relinquishing parental claim to the child and of refusing or failing to perform parental duties." 106 Under this doctrine an agency will have no better chance of securing a decree of abandonment than adoptive parents had previously. ${ }^{107}$ A definition of abandonment more favorable to the adoptive process would be acquiesence ". . . in a termination of that close relationship which normally exists between parent and child, and in the assumption by others of complete parental rights and responsibilities. ..."108 The difficulty in evolving a fair definition of abandonment lies in the need to balance the interests of the natural parent, who may have been forced to neglect the child because of temporary financial or emotional circumstances, against the desirability of getting the child settled as soon as feasible in an adoptive home. ${ }^{109}$ It would seem that for society to fulfill its primary responsibility to the child, it should be recognized that the natural parents' rights are conditioned by concomitant duties; neglect of these duties should at least place upon the delinquent parents the burden of proving that continuation of his ties with the child is desirable. ${ }^{110}$

\section{The Best Interest Doctrine.}

Perhaps the most important requirement of the entire adoption process is the court's determination of whether the adoption will further the child's best interest. ${ }^{111}$ The new Pennsylvania statute expressly provides that, over and above the other requirements of the act, the court must be satisfied "that the welfare of the person proposed to be adopted will be promoted by such adoption. . . ."112 Therefore, a natural parent may still contest the adoption on this ground even though all the other requirements are met. ${ }^{118}$ The issue then becomes whether the child's interests are better served in the adoptive home or in the home of the natural parent. ${ }^{114}$

In determining where the best interests of the child lie, whether for the purpose of examining an attack upon a proposed adoption or for

106. Pa. Stat. Ann. tit. $1, \S 1$ (Purdon Supp. 1953). Compare cases cited notes 99, 100 supra. See text following note 107 supra.

107. Ibid.

108. Rutz Adoption Case, 50 Lack. J. 25, 27 ( $\mathrm{Pa} .1948$ ) ; cf. McGill's Adoption Case, $49 \mathrm{~Pa}$. D. \& C. 374,380 (1944).

109. Even without a determination of abandonment, custody can be awarded to someone other than the natural parents. See text at note 83 supra. On the value of early adoption, see BowLBY, op. cit. supra note 40, at 101-2.

110. See Note, 60 Yale L.J. 1240, 1246 (1951).

111. See, e.g., Diana Adoption Case, $165 \mathrm{~Pa}$. Super. 12 (1949); Oelberman Adoption Case, $167 \mathrm{~Pa}$. Super. 407, 74 A.2d 790 (1950); Falck v. Chadwick, 190 Md. 466, 59 A.2d 187 (1948); see Susko Adoption Case, $363 \mathrm{~Pa} .78,81,69$ A.2d 132, 134 (1949).

112. Pa. Stat. Ann. tit. 1, $\$ 4$ (Purdon Supp. 1953).

113. See Harvey Adoption Case, $375 \mathrm{~Pa}$ 1, 99 A.2d 276 (1953). Compare Ashton Adoption Case, 374 Pa. 185, 97 A.2d 358 '(1953).

114. Ibid. 
determining custody generally, many factors have been considered: the relative economic and environmental advantages which will accrue to the child in the two homes; ${ }^{115}$ the similarity of religious affiliation; ${ }^{116}$ the degree of kinship between the child and the contesting parties; ${ }^{117}$ the number of children which the contesting parties may already have; 118 the mental and physical health of the contesting parties; ${ }^{119}$ the care which the child will receive if returned to the natural parents; ${ }^{120}$ the emotional stability of either set of parents; ${ }^{121}$ and other factors. ${ }^{122}$ Where there is an obvious deficiency in either set of parents, which occurs frequently with the natural, unwed mother, ${ }^{123}$ the decision before the court is not too difficult. However, where the relative merits of the two homes are more nearly balanced, courts must weigh a variety of factors, such as those listed above, often relying on their own instincts as to the validity of the factors which they use. ${ }^{124}$

Except where the case is clear for one side, courts are inclined to favor the natural parents on the basis of a belief that the natural parent is inherently a better parent. ${ }^{125}$ The validity of this assumption has been questioned by scientific studies, ${ }^{126}$ and consideration of the typical situation in the natural home also casts doubt upon this assumption. Half of the

115. See Harvey Adoption Case, 375 Pa. 1, 10, 99 A.2d 276, 280 (1953) (relative size of homes, nature of domestic lives in two homes).

116. Commonwealth ex rel. Kuntz v. Stackhouse, Civil No. 229, Del. County, Pa., March 11, 1954. See Purinton v. Jamrock, 195 Mass. 187, 199-200, 80 N.E. 802, 804-5 (1907); Oelberman Adoption Case, 167 Pa. Super. 407, 415, 74 A.2d 790, 794 (1950).

117. Commonwealth ex rel. Edinger v. Edinger, $374 \mathrm{~Pa} .586,98$ A.2d 172 (1953) (mother chosen over father and grandparents); Commonwealth ex rel. Kuntz v. Stackhouse, supra note 116.

118. See Commonwealth ex rel. Kuntz v. Stackhouse, supra note 116.

119. See Commonwealth ex rel. Edinger v. Edinger, $374 \mathrm{~Pa} .586,591,98$ A.2d $172,174-5$ (1953).

120. Weinbach's Appeal, $316 \mathrm{~Pa}$. 333, 338, 175 Atl. 500, 502 (1934) (mother, if she got child, would put it in foundling home).

121. Oelberman Adoption Case, 167 Pa. Super. 407, 74 A.2d 790 (1950) (natural mother showed an unstable nature by her actions in continuing to have dates with various men while pregnant and after illegitimate child born).

122. See Notes, 59 YaLE L.J. 715 (1950); 60 YALE L.J. 1240 (1951); 61 Yale L.J. 591 (1952).

123. Cf. Oelberman Adoption Case, supra note 121; Weinbach's Appeal, supra note 120; In re Adoption of Mary Alice Miller, 98 Pitr. LEgaL J. 105 (1950) (mother does not intend to admit maternity).

124. A judge's ability to make appropriate determinations in this area is limited by the inadequacies in his own training and the investigatory facilities available to him. See Note, 61 Y ALE L.J. 591, 597 (1952).

125. In Harvey Adoption Case, $375 \mathrm{~Pa} .1,10,99$ A.2d 276, 280 (1953), the court implicitly assumes that the natural home is a good one and that the adoptive home must rise above this presumption. In Ashton Adoption Case, $374 \mathrm{~Pa}$. 185, 200, 97 A.2d 368, 376 (1953), the court says "[t] he natural mother has a presumptive right to the care and custody of her child." See also Commonwealth $e x$ rel. Edinger v. Edinger, $374 \mathrm{~Pa} .586,594,98 \mathrm{~A} .2 \mathrm{~d} 172,176$ (1953), in which the court, in awarding the children to their natural mother, rather than to the father and grandparents, said that a mother is a child's ". . . most loving companion, his best teacher, his most devoted defender, and his greatest inspiration. ..."

126. Cited in Note, 61 Yale L.J. 591, 595 n.21 (1952); cf. BowlBy, op. cit. supra . note 40 at 101 et seq. 
children considered for adoption are illegitimate, ${ }^{127}$ and frequently the natural parent contesting the adoption is the unwed mother. It has been suggested that the unmarried mother is often neurotic, psychopathic, or mentally defective, and uses the child as a weapon against herself and her parents.128 At best she is subject to social and emotional pressures not conducive to supplying a stable home life. Even where the child is not illegitimate, the mere fact that the child was placed for adoption suggests that adverse emotional or financial factors exist in the natural home, whereas the whole adoption process aims at selectivity in adoptive parents.

Another factor which is considered in determining the child's best interests is the similarity of its religion to either set of contesting parents. ${ }^{129}$ In fact, the new Pennsylvania act specifically provides that whenever possible the adoptive parents shall be of the same religious faith as the natural parents, ${ }^{130}$ which means that similarity of religion is singled out as a factor to be considered in the placement process, as well as in later controversies over custody. Similar provisions are present in numerous state adoption laws. ${ }^{131}$ It may be argued that these provisions in no way promote the child's interest and are an unnecessary roadblock in the process of placing a child in an otherwise suitable home. This argument is supported by the tendency of some courts operating under these provisions to consider the religious factor as paramount, the best interest of the child notwithstanding. ${ }^{132}$ On the other hand, the provision apparently will make little change in Pennsylvania practice. In the past, while religion has been considered an important factor, normally it has not in itself been considered determinative; ${ }^{133}$ where adopting parents of the same religion are unavailable, but there is available a home suitable except for a difference in religion, the difference has rarely prevented placement. ${ }^{134}$ An attempt to evaluate the soundness of the emphasis on similar religions is complicated by the differing points of view of the various religions. It is the position of some religions that theirs is the most desirable for purposes of salva-

127. Chindren's Bureau Statistical Ser., op. cit. supra note 20 , at 7 .

128. BowlBY, op. cit. supra note 40 , at 94 .

129. Cases cited note 116 supra.

130. PA. Stat. ANN. tit. 1, $\$ 1$ (d) (Purdon Supp. 1953).

131. See, e.g., IlL. ANN. STAT. c. 4, \$4-2 (Smith Hurd Supp. 1953) ; N.Y. Soctal WeLFARE LAW \$373; R.I. GEN. LAWS c. 1772, §26 (1946).

132. See Note, 54 Col. L. REv. 376 (1954).

133. Oelberman Adoption Case, $167 \mathrm{~Pa}$. Super. 407, 415, 74 A.2d 790, 794 (1950) (child allowed to remain with foster parents despite difference in religion); Royer Adoption, 34 Del. County 402 ( $\mathrm{Pa}$. 1946). (although same religious faith is desirable, such fact alone will not prevent adoption by persons of another faith if such adoption will promote child's best interest); cf. St. George's Adoption, $45 \mathrm{~Pa}$. D. \& C. 387 (Erie County 1942) ; Purinton v. Jamrock, 195 Mass. 187, 199-200, 80 N.E. 802, 804-5 (1907). But cf. In re Margaret Riley, $20 \mathrm{~Pa}$. Dist. 745 (Phila. County 1911) (child placed in a Protestant institution, removed to Catholic orphanage solely because his parents had been Catholic). In several cases, although the custodians of the child were of a different religion, they were enjoined to raise the child in the religion of its parents. Commonwealth $e x$ rel. Lyter v. Witmer, 53 Dauph. County 377 ( $\mathrm{Pa}$. 1943); Commonweatlh ex rel. Chimienti v. Chimienti, 32 Del. County 241, 246 ( $\mathrm{Pa}$. 1943).

134. See cases cited note 133 supra. 
tion, and that denying the child the benefits of their religion does in fact work to his moral detriment. ${ }^{135}$ In addition, in the case of the child who is old enough to be aware of the practices of the religion of his parents, a change might affect him psychologically. ${ }^{136}$ Aside from the question of the benefit to any particular child provided by use of the religion criterion, disregard by the courts of religious similarities might evoke a community reaction which would have an unhealthy effect upon the adoption system generally; rejection of the agency method of placement in favor of private placements might be increased. ${ }^{137}$

In view of the importance attributed to the "best interests of the child" doctrine, it is apparent that the methods of ascertaining the best interests could be improved. Some of the criteria which are considered, such as superiority of the natural mother's love, are of doubtful validity. Some factors should perhaps be given more weight than they are presently accorded. For example, it has been urged that the motives of the adopting parents for making the adoption should be taken into consideration, ${ }^{138}$ although this is not generally done. Most important, some courts are prone to underestimate the danger to the child in being uprooted from an adoptive home. ${ }^{139}$ Judges should be provided with specific standards for determining what in fact constitutes the best interest of the child. The legislature has provided in some measure the means for obtaining these standards by enabling the judge in his discretion to rely on psychological reports supplied by agencies. ${ }^{140}$ However, judicial practice displays a certain reluctance to rely very heavily on these reports. In some measure this reluctance arises from the paucity of scientific studies on adoption and the lack of unanimity among psychologists as to precisely what standards should govern in any particular instance. ${ }^{141}$ Therefore, an attempt to develop uniform standards is extremely desirable to guide the courts toward more

135. This position is especially true of the Roman Catholic Church. Information received from The Catholic Charities, Archdiocese of Philadelphia, 1702 Summer Street, Philadelphia, Pa.

136. See Purinton v. Janrock, 195 Mass. 187, 199-200, 80 N.E. 802, 804-5 (1907).

137. Opinion expressed by Mr. Walter P. Townsend, General Secretary, Children's Aid Society of Pennsylvania, Philadelphia Bureau.

138. BowLBY, op. cit. stupra note 40, at 104-5.

139. In Harvey Adoption Case, the court said: "Nor can it be said that a child of such tender years. . may have formed such affectionate ties in its present home that it would be difficult for it to adjust itself to a new environment; an infant of that age easily forms new attachments." 375 Pa. 1, 10, 99 A.2d 276, 280 (1953). But compare BowLBY, op. cit. supra note 40, at 112: "An exceedingly common mistake has been the assumption that removing a child from his home will lead him to forget it and to start afresh. . . ." Cf. Commonwealth ex rel. Buckner v. Barr, 101 A.2d 621 ( $\mathrm{Pa}$. 1954).

140. "The said court or judge shall also hear any other testimony . . . necessary to inform the court as to the desirability of the proposed adoption, and shall also make or cause to be made an investigation by some person or public agency or private agency (with its consent) ... to verify the statements of the petition and such other facts as will give the court full knowledge as to the desirability of the proposed adoption." PA. STAT. ANN. tit. 1, \$3 (Purdon Supp. 1953). In the New York City Domestic Relations Court problems involving children are referred to a psychiatric board for evaluation and suggestion. Note, 61 Y ALE L.J. 591, 597 (1952).

141. See generally Bowlby, op. cit. supra note 40 . 
effective exercise of their discretion. Without such standards, the best interest doctrine misapplied may prevent the result desirable in any adoption procedure-a proper child in a proper home.

\section{The Approved Adoption Agency}

It is apparent that the emphasis throughout the provisions of the new Pennsylvania adoption act is on increased agency participation in the adoption process. Agencies are one of the groups selected to make investigations of adoptive homes; ${ }^{142}$ they are given custody of the child in the provisions governing termination of parental rights, ${ }^{143}$ and their staff members may advise the court as to the best interest of the child. ${ }^{144}$ Since their place in the process of a successful adoption is so important, the legislature has included in the new act a separate provision for the approval of such agencies. $^{145}$ Under this section the state Welware Department is charged with promulgating standards which an agency must meet in order to achieve or maintain an approved status. While agencies of insufficient caliber to meet the standards of the department are still able to place children for adoption, ${ }^{148}$ they do not have the benefit of receiving custody of a child after a judicial termination of parental rights; ${ }^{147}$ thus the incentive for approval will be strong. ${ }^{148}$

The Welfare Department has published a set of minimum criteria for approved agencies ${ }^{149}$ and has granted approval to an initial group of agencies. ${ }^{150}$ The character of the investigation which agencies are required by the minimum standards to make compares favorably with criteria used in other jurisdictions. ${ }^{151}$ They include the general required findings concerning matters of health, age, education and economic status, ${ }^{152}$ but, in

142. See text at note 70 supra.

143. See text following notes 85,102 supra.

144. See text at note 140 supra.

145. PA. Stat. ANN. tit. 1, \$1(b) (Purdon Supp. 1953).

146. See PA. Dep't of Welfare, The 1953 Adoption AMENDMENT (1953).

147. Sections 1.1 and 1.2 specifically refer to "approved" agencies. PA. STAT. AnN. tit. 1, $\S \S 1.1,1.2$ (Purdon Supp. 1953). See also Pa. Dep't of Welfare, op. cit. supra note 146 .

148. At the time of the legislative discussions on the new act there was considerable argument as to whether or not agencies should be required to secure a license in order to operate. However, strong interests opposed such a move and the resultant compromise was enacted. Information received from conversation with Mr. Walter P. Townsend, General Secretary, Children's Aid Society of Pennsylvania, Philadelphia Bureau.

149. Pa. Dep't of Welfare, Minimum Standards for Agencies (1954).

150. Thirty-nine agencies were approved as of March 31, 1954; list received from Pennsylvania Department of Welfare on file, Biddle Law Library, University of Pennsylvania Law School.

151. See Ill. Dep't of Public Welfare, Minmum Standards for Ceitld Placing Agencies (1953); Mich. Dep't of Social Welfare, Child Caring Institutions and Child Plactng Agencies (1953) ; Ala. Board of Public Welfare, Minmium Standards for Child-Plactng Institumions (1952) ; N.H. Dep't of Public Welfare, Rules for Licensing Private Chimd-Placing Agencies (1950) (copies on file, Biddle Law Library, University of Pennsylvania Law School).

152. Pa. DeP't of Welfare, op. cit. supra note 149, at 5-7. 
addition, the investigation must include a study of the mental health and emotional stability of the individuals involved. ${ }^{153}$ Aside from the initial study, the agency is required to keep the child and the adoptive home under surveillance throughout the six-month pre-adoption period, and three personal visits to the adoptive home are required; the child may be removed if the visits show an unsatisfactory development. ${ }^{154}$ Despite the comprehensive nature of the investigations, the qualifications which approved agencies are expected to require of their staffs appear inordinately low. ${ }^{155}$ Only one member of the staff need have social work training. ${ }^{156}$ Apparently caseworkers need have no minimum qualifications. Under such standards, it is difficult to see how the comprehensive investigation can be made properly. The investigators may have little or no knowledge of what factors should be uncovered, how they can best be uncovered, and what conclusions should be drawn from them. ${ }^{157}$

On the whole, Pennsylvania's minimum standards are unduly sketchy. Items such as caseload per caseworker and interoffice staff development have not been considered; ${ }^{158}$ no mention is made of facilities required for the care of a child until an adoptive home is found. ${ }^{159}$ Plant facilities of the agency itself are not considered, nor are the reports to the Department of Welfare required. ${ }^{160}$ Annual renewal of the approval of each agency

153. Ibid. The importance of such factors is discussed in BowlBY, op. cit. supra note 40, at 104-5. Compare Note, 59 Y ALE L.J. 715 (1950).

154. Pa. Dep't of Welfare, op. cit. supra note 149 , at $7-8$.

155. PA. DeP'T of Welfare, op. cit. supra note 149, at 4. Compare the higher standards required by Mice. Dep't of Soctal Welfare, Ceind Caring Institution iand Chind Placing Agencies 5 (1953); Ala. Board of Public Welfare, Mintmum Standards for Child-Placing Institutions 67 (1952); N.H. Dep't of Public Wedfare, Rules for Llicensing Private Child-Placing Agencies 8 (1950); Mont. Dep'r of Public Welfare, Mintmum Standards for Licensing of Chind Adoption Agenctes 6-7 (1952) (copies on file, Biddle Law Library, University of Pennsylvania Law School).

156. Pa. Dep't of Welfare, op. cit. supra note 149, at 4.

157. The Children's Aid Society in Philadelphia requires that its caseworkers have a Master's degree in social work. While such a requirement as a general standard might be too high, it indicates the minimal nature of the requirement of the Pennsylvania Department of Welfare.

158. Compare, e.g., Nebraska and Wisconsin requirements for child placing agencies, which prefer a case load of 25 to 30 cases per worker. NEB. DEP'T of Assistance \& Chitd Welfare, Minimum Standards and Goals 20 (1951); Wis. Dep't of Public Welfare, Standards for Child Welfare Agencies 54 (1948). See also Alabama reqirements for child placing agencies which provide an extensive formal training program for workers within the agency. AlA. BOARD of Publtc Welfare, Minimum Standards for Chill-Placing Agencies 68-9 (1952) (copies on' file, Biddle Law Library, University of Pennsylvania Law School).

159. Maryland and Alabama requirements provide that agencies maintain a resource of foster homes to be used should the needs of the child so require. MD.

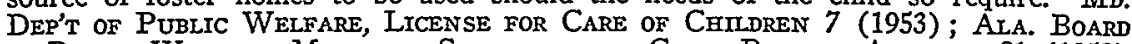
of Public Welfare, Mintmum Standards for Chimd-Placing Agencies 81 (1952) (copies on file, Biddle Law Library, University of Pennsylvania Law School).

160. Compare, e.g., Ill. Dep't of Public Welfare, Minimum Standards for Chimd-Placing Agencies 3 (1953); Mich. Dep't of Social Welfare, ChildPlacing Agencies 28 (1953) ; Ala. Board of Public Welfare, Minimum Standards For Child-Placing Agencies 85 (1952); Tex. Dep't of Public Welfare, Mrnimum Standards, Chimp-Placing Agencirs 11 (1951) (copies on file, Biddle Law Library, University of Pennsylvania Law School). 
is, happily, provided for; ${ }^{101}$ reports from the agencies might facilitate the renewal process,

\section{ConCluston}

An examination of some of the problems which arise in the area of adoption and of one modern legislative approach to their solution reveals the important part played by the adoption agency today and our dependence for a solution of the problems on the cooperation of adequate, qualified agencies. Because public welfare departments today are equipped to fill only a supervisory capacity in the adoption process, the public must continue to rely on the work of private agencies. But it is important that this work meet high standards, defined and enforced by the state, if the adoption process is to be effective; an adoption must be a skilled process if it is to result in a statisfied natural parent, a proper home for the child, and adoptive parents well adjusted to their new responsibilities. ${ }^{162}$

Independent placements are inferior to the agency process in many respects: where an individual placement is made, no trained personnel is available for counseling natural parents, for assessing the potentialities of the child, or for predicting the suitability of the prospective home. Agency placement offers the best opportunity for the operation of a voluntary relinquishment procedure, and for the collection of statistics pertinent to the development of a more scientific adoption program. Clearly, ultimate elimination of independent placements should be the goal. While this can be only a long range aim, more immediate progress can perhaps be made by continuing the advancements initiated in recent statutes, by improving, for example, the abandonment doctrine and the procedure for reports by recipients of children. In particular, an attempt should be made to evolve more rational criteria for determining a child's best interest and to assist courts in implementing these criteria. Experience with the Pennsylvania act may show that it needs strengthening along some of the lines which have been suggested, but it nevertheless represents a substantial step forward. Further advances in any of the proposed directions can come only with an increasing public awareness of the problems and financial support for the expansion of public and private facilities. ${ }^{163}$ The significance to the community of providing its children with adequate opportunity to develop into well-adjusted adults, ${ }^{184}$ if brought to public attention, should assure interest in improving the adoption process.

161. See Section 1(b).

162. See BowlBY, op. cit. supra note 40 , at 101 .

163. In Los Angeles a citizer's committee on adoption problems has been functioning for sometime. Federal Security Agency, Children's Bureau, The Citizens ADOPTTON CoMmitTeE of LOS ANGeles County (1952). In Pennsyivania it has been stated that the failure of the community in Allegheny County to support the Community fund drives in 1949 and 1950 indicate that pubilc agencies which depend on that source will have to retrench their activties. The private agencies in this area are also having difficulties. In 1947 two maternity homes ceased placing children. Cox, Pennsylvania's Need-An Adequate Adoption Placement Program 22 PA. B.A.Q. 154,160 (1951).

164. On the relationship between unsatisfactory parental relationships in childhood and crime, see BowLBY, op cit. supra note 40 , at 30 et seq. 